\title{
Szemfenéki arteria centralis retinae érelzáródás miatt kialakult hirtelen látásromlás spontán restitúciója cilioretinalis artéria jelenlétében
}

\author{
Angeli Orsolya dr. - Nagy Zoltán Zsolt dr. - Schneider Miklós dr. \\ Semmelweis Egyetem, Általános Orvostudományi Kar, Szemészeti Klinika, Budapest
}

\begin{abstract}
A szemfenéki artériás érelzáródás hirtelen, fájdalmatlan látásvesztéssel járó, sürgősségi ellátást igénylő állapot. A retina vérellátásáról a belső magvas rétegig a szemgolyó két különálló artériás rendszere közül a legtöbbször csak az arteria centralis retinae és ágrendszere gondoskodik. A cilioretinalis artéria egy olyan anatómiai variáns, melynek révén a macula vérellátásához a ciliaris artériás rendszer is hozzájárulhat, ami az arteria centralis retinaet érintó okklúzió bekövetkezése esetén döntő szerepet játszhat a centralis látás megőrzésében. Egy cilioretinalis artériával rendelkező 67 éves nőbeteg centralis retinalis artériás okklúziót követő spontán látásjavulását mutatjuk be fundusfotográfia és optikaikoherencia-tomográfiás felvételekkel. A páciens 1 hetes panaszokkal érkezett, ezért akut terápiában már nem tudtuk részesíteni. Kontrollvizsgálatai során azonban állapota fokozatosan javult, és spontán visszanyerte az 1,0-s látásélességét. A macula vérellátásában részt vevő cilioretinalis artéria jelenléte esetén arteria centralis retinae érelzáródást követôen is lehetséges a látásélesség megôrzése, illetve látásromlás esetén az elzáródás előtti látásélesség spontán visszatérése.
\end{abstract}

Orv Hetil. 2019; 160(29): 1146-1152.

Kulcsszavak: centralis retinalis artériás okklúzió, cilioretinalis artéria, fundusfotográfia, optikaikoherencia-tomográfia

\section{Spontaneous visual recovery following a central retinal artery occlusion in a patient with a cilioretinal artery}

Retinal arterial occlusion causes acute, painless vision loss, and it requires immediate emergency care. There are two separate arterial systems (retinal and ciliary) in the retina, and in most cases only the central retinal artery and its branches supply blood to the inner retinal layers. Cilioretinal artery is an anatomical variant, which can also supply blood to the macula from the ciliary arterial system, and in the case of a retinal arterial occlusion, the cilioretinal artery could save central vision. We report a case of a 67-year-old woman who suffered a central retinal arterial occlusion while having a patent cilioretinal artery and she had a complete recovery of her central visual acuity. A series of fundus photography and optical coherence tomography images are presented that were taken during follow-up. The patient's complaints started one week before she presented in our department therefore acute therapy was not given. However, during the course of the follow-up her status gradually improved, and she finally regained $1,0(20 / 20)$ visual acuity. In the presence of a cilioretinal artery following a central retinal arterial occlusion, there is a chance of visual acuity preservation.

Keywords: central retinal arterial occlusion, cilioretinal artery, fundus photography, optical coherence tomography

Angeli O, Nagy ZZs, Schneider M. [Spontaneous visual recovery following a central retinal artery occlusion in a patient with a cilioretinal artery]. Orv Hetil. 2019; 160(29): 1146-1152.

(Beérkezett: 2019. február 2.; elfogadva: 2019. február 28.) 


\section{Rövidítések}

CLRA $=($ cilioretinal artery $)$ cilioretinalis artéria; $\mathrm{CRA}=($ cent ral retinal artery) arteria centralis retinae; $\mathrm{CRAO}=($ central retinal artery occlusion) az arteria centralis retinae elzáródása; FLAG = (fluorescein angiography) fluoreszcein angiográfia; $\mathrm{GCC}=($ ganglion cell complex $)$ ganglionsejtréteg; $\mathrm{MT}=(\mathrm{ma}-$ cular thickness) maculavastagság; OCT $=$ (optical coherence tomography) optikaikoherencia-tomográfia; OCTA $=$ (optical coherence tomography angiography) optikaikoherencia-tomográfia alapú angiográfia; $\mathrm{PCA}=$ (posterior cerebral artery) arteria ciliaris posterior

A szemgolyó vérellátását az arteria ophthalmicából eredő ciliaris és retinalis artériás rendszer két, egymástól teljesen elkülönülő érhálózata biztosítja. A rövid hátsó ciliaris artériák (aa. ciliares posteriores breves) az ínhártyát átfúrva látják el az érhártyát (choroidea), amely a külső retina vérellátásáért felelős. Az arteria centralis retinae elsődlegesen a belső retina ellátását biztosítja.

$\mathrm{Az}$ arteria centralis retinae elzáródása (CRAO) ritka szemészeti sürgősségi állapot, mely hirtelen kialakuló, fájdalmatlan látásvesztéssel jár. Ritka esetekben egyszerre mindkét szem is érintett lehet [1].

A posterior ciliaris rendszerhez tartozó cilioretinalis artéria (CLRA) a retina leggyakoribb kongenitális éranomáliája, melynek jelenléte esetén a két artériás rendszer ellátási területei között átfedés keletkezik [2]. Ennek köszönhető, hogy az arteria centralis retinaet érintő centralis vagy ágokklúzió során, a maculát is ellátó CLRA jelenléte esetén a macula vérellátása megmaradhat, és a centralis látás részben vagy teljesen visszanyerhető.

\section{Esetbemutatás}

Egy 67 éves nőbeteg a területi szemészeti szakrendelésről érkezett Klinikánkra maculaödéma és időskori maculadegeneráció diagnózisával. Elmondása szerint 7 napja hirtelen megromlott a látása a jobb szemén, úszkáló felhőket és szürke foltokat látott. Szemészeti anamnézisében szürkehályog-mütét szerepelt mindkét szemén. Általános anamnéziséből egy 10 évvel korábbi mélyvénás trombózis, magasabb koleszterinszint, 15 éve ismert és kezelt magas vérnyomás és a dohányzás emelendő ki. Szedett gyógyszerei: vérnyomáscsökkentők (amlodipin, perindopril, betaxolol), savcsökkentő (pantoprazol) és nyugtató (alprazolám).

A látóélesség vizsgálata során 0,1 -es $(20 / 200)$ visus volt megállapítható a jobb szemén, ami mínusz 1,0 dioptriájú szférikus lencsével szubjektíven kissé javítható volt. A bal szemén visusa 1,0 (20/20) volt.

A szem elülső szegmentumának vizsgálata során békés múlencsés állapotot láttunk kóros eltérés nélkül, szemnyomása normális volt.

A pupillatágítást követő szemfenéki vizsgálat eredményeként a jobb szem maculaödémája és arteria centralis retinae elzáródás $(\mathrm{CRAO}=$ central retinal artery oc-

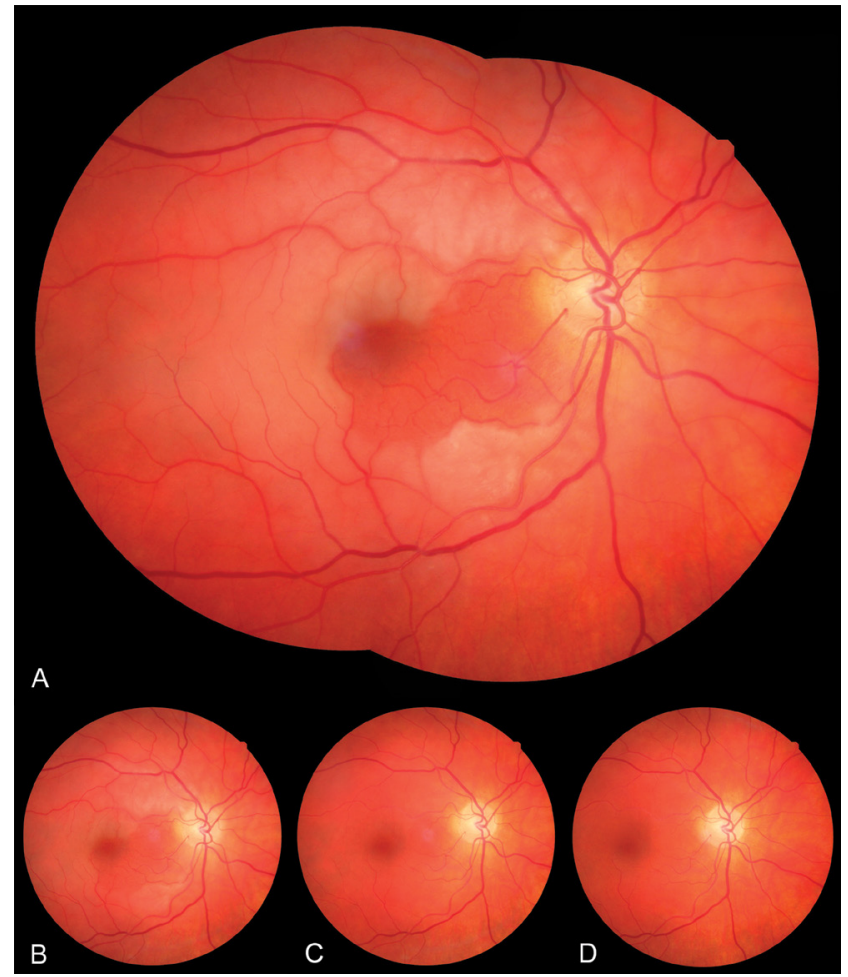

1. ábra

Fundusfotó az első megjelenéskor (A), 2 héttel (B), 1 hónappal (C) és 6 hónappal (D) az elzáródás után

clusion) volt megállapítható a temporalis felső és alsó érárkádok érintettségével.

A beteg jobb szeméról szemfenéki (fundus-) fotókat is készítettünk a NIDEK AFC-210 (Nidek Co. Ltd, Hamagori, Japán) típusú, 45 fokos látószögű funduskamerával [3], amit minden kontrollvizsgálat alkalmával megismételtünk. Az első vizit során készült fotón jól látszik, hogy a papilla temporalis alsó részén eredő, a papillomacularis terület és a macula jelentős részét ellátó cilioretinalis artéria miatt annak ellátási területén a keringés megtartott volt, maculaödéma a jó keringésû területen nem volt, csak azon kívül. Az arteria centralis retinae ágai kifejezetten vékonyak, a vénák normális tágasságúak voltak ( $1 /$ A ábra).

A bal szem vizsgálata során ép papilla, temporalisan felül cilioretinalis artéria, a maculatájon pigmentegyenetlenség, pigmentrög volt látható; a periféria ép volt.

A maculavastagságnak ( $\mathrm{MT}=$ macular thickness) és a belső retinában elhelyezkedő ganglionsejtréteg (GCC = ganglion cell complex) vastagságának elemzéséhez minden viziten optikaikoherencia-tomográfiás (OCT-) vizsgálatot (Zeiss CIRRUS HD-OCT Model 4000; Carl Zeiss Meditec, Inc., Dublin, CA, Amerikai Egyesült Államok) is végeztünk. Az OCT segítségével mikrométeres, szövettani felbontású keresztmetszeti képeket kapunk a retina adott szegmenséről [4].

Az OCT maculavastagság-elemző felvételeken jól nyomon követhető volt az érintett terület vastagságának időbeli változása. Az első vizitnél a macula ödémája lát- 


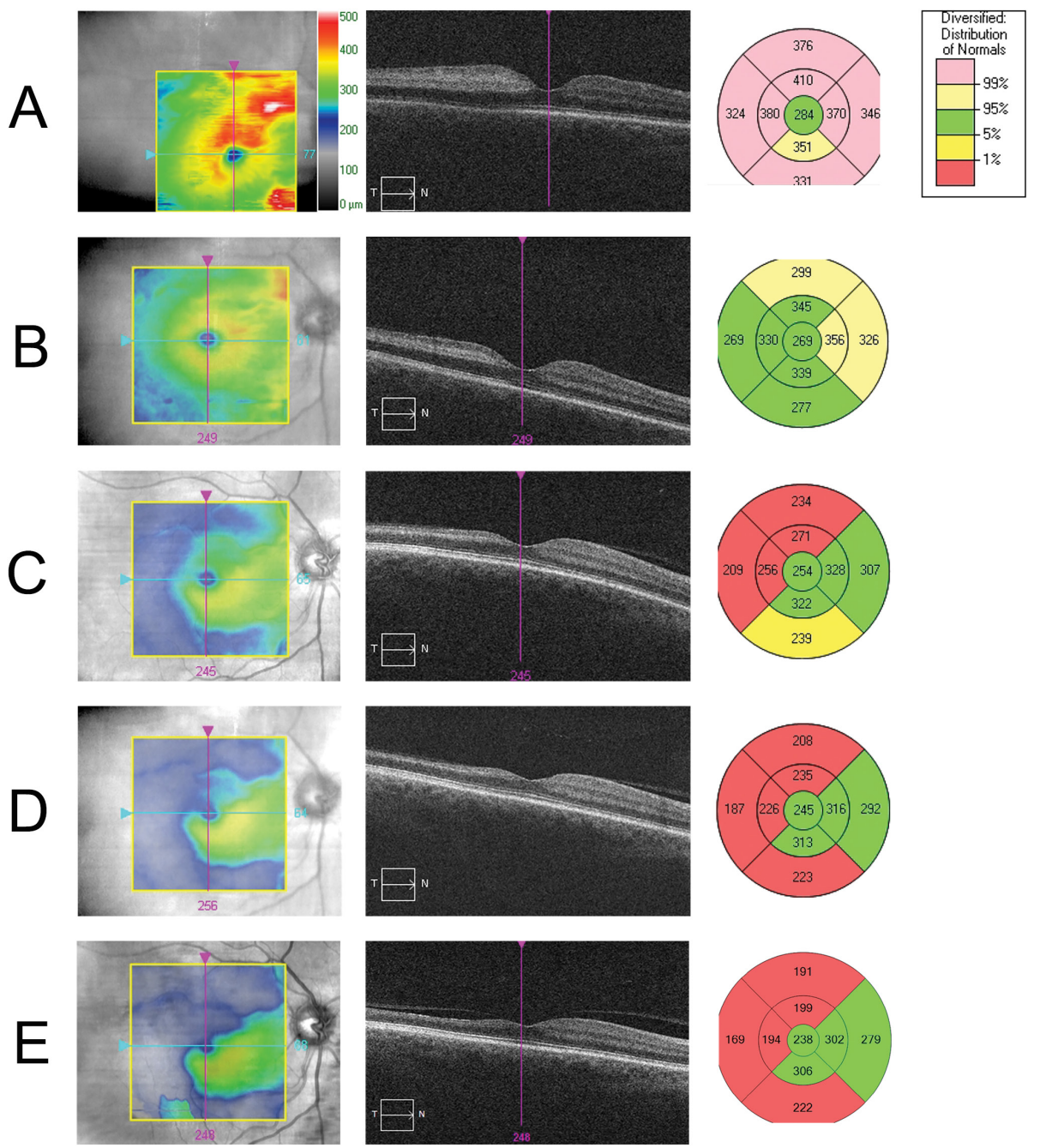

2. ábra $\mid$ Maculavastagsági térkép, OCT B-scan felvétel és szektoriális maculavastagsági térkép az első megjelenéskor (A), 2 héttel (B), 1 hónappal (C), 2 hónappal (D) és 3,5 évvel (E) az elzáródás után. A: diszkrét denzitás- és vastagságfokozódás az ödéma következtében; B: csökkenő ödéma, látszólag normáltartományban lévő maculavastagság; C-E: fokozódó atrófia a macula temporalis részén

OCT = optikaikoherencia-tomográfia

ható temporalis túlsúllyal, ezért a vastagság a centralis szektort leszámítva a normális tartományon felül volt (2/A ábra). Tekintettel a 7 napos panaszokra, akut szemészeti kezeléstől (bulbusmasszázs, gyors szemnyomáscsökkentés, csarnokpunkció, intramuscularis görcsoldó, sebészi kezelés, thrombolysis) már nem várhattunk javulást, ezért a beteg obszervációja mellett döntöttünk, és az embóliaforrás felderítése céljából a pácienst háziorvosához irányítottuk.

$\mathrm{Az}$ artériás elzáródásokat jellemzően a keringésből kiesett területek atrófiája követi. A beteg első jelentkezését követô 1 hetes kontrollvizsgálaton (az elzáródás után 2 héttel) a jobb szem visusa 0,2-re javult, a maculaödéma csökkent, az atrófia azonban ekkor még nem volt megfigyelhető, ezért a maculavastagság látszólag a normális tartományba került, ami félrevezető lehet $(2 / B$ ábra). A GCC-elemzéskor ennek megfelelően normális vastagságértékeket láttunk az összes szektorban $(3 / A$ ábra).
Az 5 hetes kontrollon a beteg panasza csökkent, a jobb szem visusa 0,25 -re javult, a maculában ödéma már nem volt látható $(2 / C$ ábra). Az ödéma megszúnésével az elzáródott ér ellátási területének megfelelően temporalisan vastagságcsökkenés, atrófia volt detektálható, amit az OCT-készülék szektorokat ábrázoló felvételén az érintett szektorokban piros színnel jelölve láthatunk (2/ $C-E$ ábra). A maculavastagság csökkenésével párhuzamosan a maculában mérhető az ischaemiára rendkívül érzékeny GCC-vastagság csökkenése is, az atrófia részben ezen sejtek pusztulását jelzi [5] (3/B ábra). A szemfenéken neovascularisatio nem volt látható, gonioszkópiás vizsgálattal körben teljesen nyitott csarnokzugot láttunk, goniorubeosis nélkül.

Időközben a beteg belgyógyászati kivizsgálása is befejeződött, eredményeiből a carotis-UH-lelet emelendő $\mathrm{ki}$, amelyben jobb oldalon helyenként fali meszesedéseket írtak le, szignifikáns szúküllet nélkül. Hypertoniájának gyógyszeres kezelését módosították, perindopril/ 

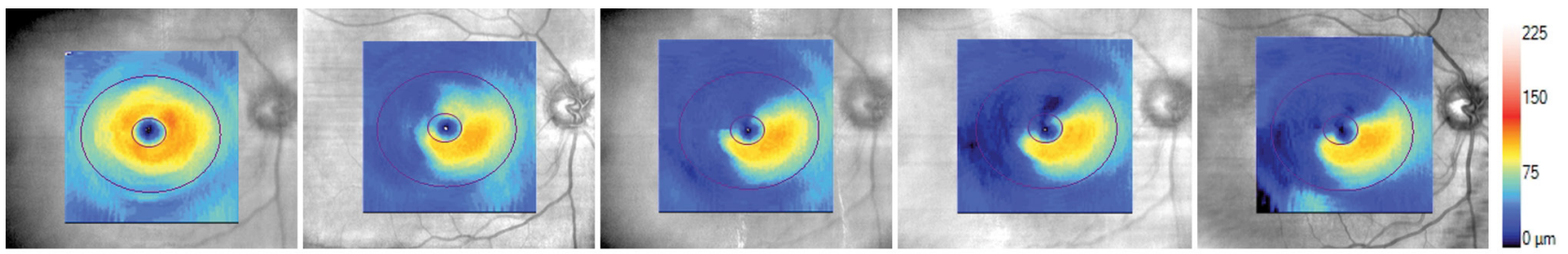

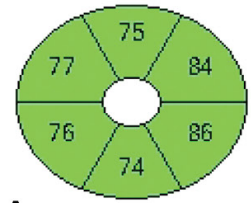

A

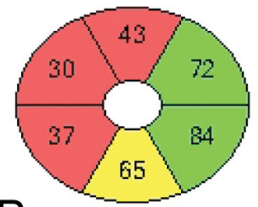

B

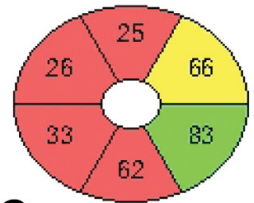

C

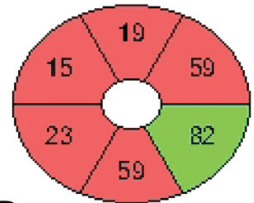

D

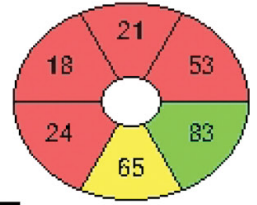

E

3. ábra | Ganglionsejt-vastagság térkép és szektoriális ábrázolás 2 héttel (A), 1 hónappal (B), 2 hónappal (C), 6 hónappal (D) és 3,5 évvel (E) az elzáródás után
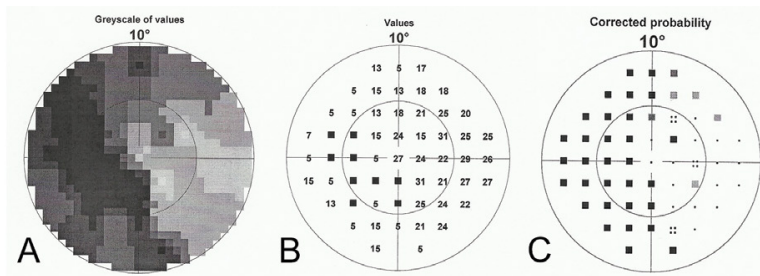

$\cdot P>5$

$P<5$
$P<2$
$P<1$

4. ábra

Látótérvizsgálat 4 hónappal az elzáródás után: 10 fokos látótér szürkeskálás ábrázolása (A), küszöbérték ábrázolása (B) és normál látóterű alanyhoz viszonyított korrigált valószínúségi ábrázolása $(\mathrm{C})$

amlodipin kombinált kezelést, valamint karvedilolt kapott. Ezeken kívül acetilszalicilsav-kezelést indítottak, és koleszterincsökkentőt (rozuvasztatin) is kapott. Szívultrahangján normális üregi méretek, hiperkinetikus falmozgások, funkcionálisan ép billentyúk, normális Colordoppler volt látható megtartott szisztolés bal kamrai funkcióval, relaxációs zavarral. Pitvarfibrilláció, thrombus nem volt detektálható.

A 2 hónapos kontrollvizsgálaton a jobb szem visusa 0,5-re javult. A szemfenéki kép és a látóélesség alapján spontán funkciójavulás látszott, neovascularisatio nélkül. A GCC-vastagság az összes szektorban mérsékelten csökkent az 5 hetes kontrollhoz képest ( $3 / C$ ábra). 3 hónappal az elzáródást követően a visus változatlanul 0,5 volt. A 4 hónapos vizsgálaton a visus 0,4 -re romlott, a maculavastagság érdemben már nem csökkent $(2 / D$ ábra). Ezen az ellenőrző vizsgálaton 10 fokos automata látótérvizsgálat is történt: a jobb szemen a centrum, a temporalis alsó kvadráns és részben a temporalis felső kvadráns alsó részének megtartottsága látszott, máshol teljes kiesés vagy jelentős érzékenységcsökkenés volt detektálható (4. ábra). A bal szem látótere ép volt.

$\mathrm{Az} 5$ hónapos kontrollvizsgálaton a jobb szem visusa 0,7-re javult, és fél évvel az elzáródás után már 0,9 volt. A féléves kontrollon a GCC érdemben már nem csökkent a korábbi kontrollokhoz képest (3/D ábra).

A páciens ezt követően csak egy évvel később jött el szemészeti kontrollra, ekkor a jobb szem visusa már 1,0 volt, a teljes centralis látóélesség spontán visszatért.
A három és fél évvel az elzáródást követően készült maculavastagság- és ganglionsejtvastagság-elemző felvételeken gyakorlatilag ugyanaz az állapot volt látható, mint a 6 hónapos kontrollvizsgálaton $(2 / E$ és $3 / E$ ábra).

A követési idő 4. évében elérhetővé vált az optikaikoherencia-tomográfia alapú angiográfia (OCTA) vizsgálómódszer is. Az OCTA a meglévő OCT-készülékek angiográfiás szoftverrel továbbfejlesztett változata, amelynek segítségével noninvazív módon, kontrasztanyag beadása nélkül tudjuk megjeleníteni a szemfenéki ereket [6]. Az OCTA-vizsgálat során $3 \times 3$ és $6 \times 6$ mm-es maculafelvételeket készítettünk a Zeiss CIRRUS Angioplex készü-
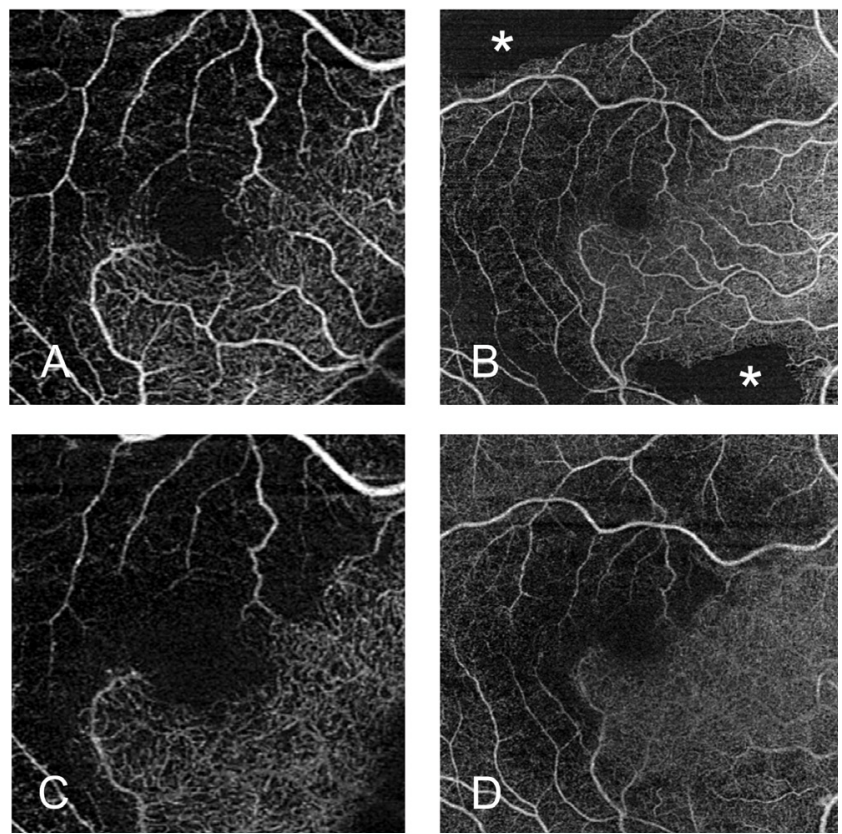

5. ábra

OCT-angiográfiás felvétel a maculáról 3,5 évvel az elzáródás után; $3 \times 3 \mathrm{~mm}$-es felvétel a felületes (A) és mély (C) érhálózatról; $6 \times 6 \mathrm{~mm}$-es felvétel a felületes (B) és mély (D) érhálózatól. A felvételeken jól látható a macula temporalis és felső részének érsűrúség-csökkenése, amely a kép többi részéhez képest sötétebb. A $6 \times 6$ mm-es B kép bal felső és jobb alsó sarkában lévő, csillaggal jelölt fekete területek mútermékek

OCT $=$ optikaikoherencia-tomográfia 
lékkel a felületes és a mély retinalis érhálózatról [7]. Az OCTA-felvételeken jól látható volt a macula temporalis és felső részén a korábbi elzáródásnak megfelelő területek rekanalizációja, jelentős érsűrúség-csökkenés mellett. A cilioretinalis artéria által ellátott területen megtartott volt a kapillárissürüség (5. ábra).

\section{Megbeszélés}

A XIX. század végén és a XX. század elején intenzív szemészeti anatómiai kutatások folytak, melyek nagy részében a szem vérelláását, illetve a cilioretinalis artériát vizsgálták $[8,9]$. A CLRA pontos eredésére vonatkozóan kissé eltéró eredmények születtek, de mai tudásunkkal megegyezően mindegyik tanulmány a posterior ciliaris érrendszerből (közös törzzsel az arteria ophthalmicából vagy a posterior ciliaris arteria [PCA] egy ágaként) származtatta a CLRA-t [10].

A CLRA a szemfenéki képen jellemzően hurokszerúen indul ki a látóidegfó szélén, a leggyakrabban temporalisan, és a macula felé húzódik. Pontos kilépési helye a papilla szélén, darabszáma, mérete, vérellátási területe egyénenként nagyon változó lehet, de akár az egész retina vérellátásához hozzájárulhat [1, 10-14]. A jelen esettanulmányban bemutatott páciens CLRA-ja a látóidegfó temporalis széléről indulva húzódott a macula felé, és macularis végénél 4 ágra osztódva látta el a macula nasalis és részben az alsó részét, illetve a foveát is (1. ábra).

Önmagában a szemfenéki kép alapján nem lehet megbízhatóan megállapítani, hogy valóban CLRA-ról van-e szó, ugyanis hasonló morfológiával az adott ér a CRA egy korai intraneuralis ága is lehet. A CLRA biztos identifikálása szövettani feldolgozással, illetve fluoreszcein angiográfiával (FLAG) lehetséges: a FLAG-vizsgálat során a CLRA a chorioideával egy időben, még a CRA telődése előtt rajzolódik ki $[10,15,16]$. Mivel betegünk első megjelenésekor panaszai már 1 hetesek voltak, a szemfenéki morfológia egyértelmû volt, és a vizsgálatnak terápiás konzekvenciája nem lett volna, FLAG-vizsgálatot nem végeztünk.

Arteria centralis retinae elzáródás esetén a látásvesztés mértéke és reverzibilitása nagymértékben függ az elzáródás pontos helyétől (centralis vagy ágokklúzió), illetve az elzáródás és a kezelés között eltelt időtől, valamint egy esetleges CLRA jelenlététól [17]. A bemutatott esetnél a beteg a látását a CLRA jelenlétének köszönhetően nem vesztette el teljesen, „felhôt”, illetve szürke foltokat látott.

A CRAO kezdeti fázisában érzékelhető objektív szemfenéki változásokat tájékozódó réslámpás szemfenékvizsgálattal, illetve precízebben FLAG- és OCT/OCTA vizsgálattal detektálhatjuk. A CRAO-ra jellemző kezdeti elváltozások a következők: a foveában cseresznyepiros folt $(90 \%)$, homályos retina $(58 \%)$, „sápadt” retina a hátsó póluson (39\%), a CRA szúkülete (32\%), papillaödéma (22\%). A késôi fázisban látható eltérések: opticus atrófia (91\%), CRA-szúkület (58\%), cilioretinalis kollaterálisok jelenléte (18\%) és pigmentepithelium-eltérések a maculában (11\%) [1]. Esetünknél a homályos, sápadt retina, illetve a szúkebb artériák az elzáródásnak megfelelően az első vizit során készült szemfenéki fotón jól láthatók, a cseresznyepiros folt a foveát is ellátó CLRA jelenléte miatt hiányzott (1. ábra).

A ganglionsejtek rendkívül érzékenyek az akut ischaemiára. Mennyiségük a macula közepe felé haladva fokozatosan nő, ezért a retina vizenyője, vastagodása és homályossága is a maculában a leginkább szembetúnő [5]. A CRAO késői fázisában a sápadtság megszúnése után a retina visszanyeri áttetszőségét, de a belső rétegekben irreverzibilis károsodás megy végbe. A ganglionsejtek fokozatos pusztulása ebben a fázisban jellegzetes, ami betegünk esetében is jól követhetô volt (3. ábra). Krónikus CRAO esetén a macula atrófiássá válik, egyes esetekben a pigmentepithelium granuláltsága is megfigyelhető [1].

Hayreh és mtsai hosszú távú megfigyelései alapján semmilyen érelváltozás nem látható a szemfenéken, amennyiben az elzáródás legfeljebb 105 percig tart, tehát a normális szemfenéki kép nem zárja ki az akut érelzáródás lehetőségét. A 105 percnél tovább tartó elzáródásnál megfigyelhetô az erek szúkebbé válása [1].

A papilla és az idegrostréteg elváltozásai is diagnosztikus értékúek. 97 percnél tovább tartó CRAO esetén a papilla egyre sápadtabbá válik, 240 percnél tovább tartó okklúzió következtében az idegrostréteg vastagsága és láthatósága drasztikusan csökken, a nervus opticus atrófiássá válik, ami tartós látáskárosodást von maga után. A köztes időben a retina alacsony ischaemiás toleranciája miatt a károsodás mértéke egyenesen arányos az okklúzió óta eltelt idóvel [18].

A legújabb klinikai vizsgálatok alapján a fenti makroszkópos elváltozásoknál jóval korábban kimutatható a retina mikroszkópos hypoxiás károsodása. Tobalem és mtsai vizsgálatukban igazolták, hogy már 12-15 perc hypoxia is progresszív, szignifikáns, irreverzibilis károsodást okoz a ganglionsejtrétegben. Ez a szúk idôintervallum világossá teszi, hogy a legtöbb esetben miért nem sikeresek a CRAO terápiás kísérletei. Ugyanakkor sosem tudhatjuk biztosan, hogy pontosan mikor kezdődött a komplett elzáródás, illetve időszakos reperfúziós periódusok is lehetnek az elzáródást követően az átmeneti spasmus, illetve az embólus vagy thrombus feltöredezése következtében. Ebből adódóan a vélhetően többórás CRAO esetén is érdemes megkezdeni az adekvát terápiát, mert a klinikai kép alapján nem lehetünk biztosak az elzáródás teljességében és kezdeti idôpontjában. Inkomplett elzáródás esetén rendszerint hatásosabb a terápia, azonban egyik alkalmazott módszer sem bizonyult klinikailag abszolút eredményesnek. 48 órán túl már nem várható javulás semmilyen jelenleg ismert kezeléssel [19].

Az elzáródást követő egy hét alatt spontán látásjavulás előfordulhat, ennek mértékét döntóen a CRAO altípusa határozza meg. A CRAO a patogenezis, a klinikai megjelenés és a terápia figyelembevételével 4 különböző altí- 
pusra osztható: 1. permanens elzáródással járó nonarteritises CRAO, 2. nonarteritises CRAO cilioretinalis artéria jelenlétével, 3 . arteritises CRAO óriássejtes arteritisszel és 4. tranziens nonarteritises CRAO. A legnagyobb eséllyel (82\%) a tranziens típusnál várható javulás, mely esetben az elzáródás nem komplett, és rendszerint embólus, a perfúziós nyomás csökkenése vagy vasospasmus áll a hátterében. CLRA jelenléte esetén 67\%, a nonarteritises típusban $22 \%$ a várható javulás esélye, az arteritisesnél pedig rendszerint nem változik a visus az első egy hét alatt [11].

Számos esettanulmány és eredeti közlemény mutatja be a jelen esethez hasonlóan a CLRA látást megőrző szerepét a retinalis artériás/vénás érrendszerben bekövetkező érelzáródás után [20-23].

Előfordulhat azonban az is, hogy maga a CLRA záródik el (CLRAO = cilioretinal arterial occlusion). A CLRA elzáródása esetén az ér ellátási területének megfelelően látótérkiesés alakul ki. Mivel a CLRA a leggyakrabban temporalisan helyezkedik el, elzáródása döntően a maculát is érintő, centralis látótérkiesést okoz, megtartott perifériás látótérrel [1].

A hirtelen látásromlások hátterében számos szemészeti és belgyógyászati ok állhat, melyek közül az egyik legsúlyosabb a szemfenéki artériás érelzáródás. Rudkin és mtsai kimutatták, hogy közel 40\%-os a stroke és egyéb cardiovascularis esemény bekövetkezésének rizikója az artériás szemfenéki érelzáródáson átesett betegeknél. A szemfenéki erek állapota húen tükrözi a szervezet általános érrendszeri statusát, ezért kiemelten fontos ebben a betegcsoportban a részletes neurológiai kivizsgálás és a stroke-prevenció, amely többek között a magas vérnyomás, a hyperlipidaemia, a diabetes, az atherosclerosis és az egyéb szív-ér rendszeri betegségek kezelésével érhető el [24]. A stroke vagy cardiovascularis esemény kialakulásának valószínűsége a szemfenéki érelzáródást követő napokban a legmagasabb [25]. Az aktuális amerikai irányelvek [26-29] szerint az elzáródás diagnózisát követően a szemész szakorvos a beteget azonnal strokecentrummal rendelkező sürgősségi osztályra kell, hogy küldje a korai preventív kezelés érdekében.

A centralis artériás okklúzió azonnali, sürgősségi ellátást igénylő állapot, ezért fontos a gyors diagnózis és a betegek megfelelő ellátóhelyre történő irányítása. Szerencsés esetekben, ha az állapot tranziens, vagy - esetünkhöz hasonlóan - CLRA is ellátja a maculát, a látásvesztés nem teljes, és idővel a centralis látás részben vagy teljesen, spontán visszatérhet.

Anyagi támogatás: A közlemény megírása és a kapcsolódó kutatómunka anyagi támogatásban nem részesült. Az OCT-angiográfiás vizsgálatokhoz a Zeiss CIRRUS Angioplex készüléket a Carl Zeiss Technika Kft. bocsátotta rendelkezésünkre.
Szerzôi munkamegosztás: A. O.: Az anamnézis áttekintése, fundusfotó és OCT-felvételek válogatása, irodalomkutatás, a kézirat írása, a kézirat végleges változatának elfogadása. N. Z. Zs.: A kézirat revíziója, a kézirat végleges változatának elfogadása. S. M.: Beteginterakció és diagnózis, szemészeti vizsgálatok, a fundusfotó és az OCT-felvételek készítése, a kézirat revíziója, a kézirat végleges változatának elfogadása. A cikk végleges változatát valamennyi szerző elolvasta és jóváhagyta.

Érdekeltségek: A szerzőknek nincsenek érdekeltségeik.

\section{Irodalom}

[1] Hayreh SS. Acute retinal arterial occlusive disorders. Prog Retin Eye Res. 2011; 30: 359-394.

[2] Awan KJ. Arterial vascular anomalies of the retina. Arch Ophthalmol. 1977; 95: 1197-1202.

[3] Chin EK, Ventura BV, See KY, et al. Nonmydriatic fundus photography for teleophthalmology diabetic retinopathy screening in rural and urban clinics. Telemed J E Health 2014; 20: 102108.

[4] Fujimoto JG. Optical coherence tomography for ultrahigh resolution in vivo imaging. Nat Biotechnol. 2003; 21: 1361-1367.

[5] Hayreh SS. Prevalent misconceptions about acute retinal vascular occlusive disorders. Prog Retin Eye Res. 2005; 24: 493-519.

[6] Kashani AH, Chen CL, Gahm JK, et al. Optical coherence tomography angiography: a comprehensive review of current methods and clinical applications. Prog Retin Eye Res. 2017; 60: 66-100.

[7] CIRRUS OCT with AngioPlex from ZEISS. Making the revolutionary routine. Product Brochure. Available from: https://applications.zeiss.com/C1257A290053AE30/0/EA4C6AF9FD 8F2DD1C12580F800612D2A/\$FILE/CIRRUS_AngioPlex_ brochure_EN_31_011_0004I.pdf [accessed: July 26, 2018].

[8] Randall BA. Cilio-retinal or aberrant vessels. Trans Am Ophthalmol Soc. 1887; 4: 511-517.

[9] Duke-Elder S, Wybar KC. System of ophthalmology. The anatomy of the visual system (Volume 2). Kimpton, London, 1961; p. 345.

[10] Hayreh SS. The cilio-retinal arteries. Br J Ophthalmol. 1963; 47 : 71-89.

[11] Hayreh SS, Zimmerman MB. Central retinal artery occlusion: visual outcome. Am J Ophthalmol. 2005; 140: 376-391.

[12] Hayreh SS. The central artery of the retina. Its role in the blood supply of the optic nerve. Br J Ophthalmol. 1963; 47: 651-663.

[13] Hayreh SS. Arteries of the orbit in the human being. Br J Surg. 1963; 50: 938-953.

[14] Hegde V, Deokule S, Matthews T, et al. A case of a cilioretinal artery supplying the entire retina. Clin Anat. 2006; 19: 645647.

[15] Justice J Jr, Lehmann RP. Cilioretinal arteries. A study based on review of stereo fundus photographs and fluorescein angiographic findings. Arch Ophthalmol. 1976; 94: 1355-1358.

[16] Chawla R, Azad SV, Takkar B, et al. Swept source optical coherence tomography-angiography of an infarct of a small intra-neural branch of central retinal artery simulating cilio-retinal artery. Indian J Ophthalmol. 2018; 66: 850-851.

[17] Rudkin AK, Lee AW, Chen CS. Vascular risk factors for central retinal artery occlusion. Eye (Lond). 2010; 24: 678-681.

[18] Hayreh SS, Jonas JB. Optic disk and retinal nerve fiber layer damage after transient central retinal artery occlusion: an experimental study in rhesus monkeys. Am J Ophthalmol. 2000; 129: 786-795 
[19] Tobalem S, Schutz JS, Chronopoulos A. Central retinal artery occlusion - rethinking retinal survival time. BMC Ophthalmol. 2018; 18: 101 .

[20] Ozdemir H, Karacorlu M, Karacorlu SA, et al. Localized foveal detachment in a patient with central retinal artery occlusion with cilioretinal sparing. Eur J Ophthalmol. 2012; 22: 492-494.

[21] Doguizi S, Sekeroglu MA, Anayol MA, et al. Central retinal artery occlusion with double cilioretinal artery sparing. Retin Cases Brief Rep. 2019; 13: 75-78.

[22] Gaier ED, Miller JB, Loewenstein JI. Combined central retinal vein occlusion and central retinal arterial obstruction with cilioretinal artery sparing. Ophthalmology 2017; 124: 576.

[23] Mańkowski W, Wylegała E. Optical coherence tomography (OCT) in central retinal occlusion with sparing cilioretinal artery - a case report. Klin Oczna 2008; 110: 304-307.

[24] Rudkin AK, Lee AW, Aldrich E, et al. Clinical characteristics and outcome of current standard management of central retinal artery occlusion. Clin Exp Ophthalmol. 2010; 38: 496-501.

[25] Biousse V, Nahab F, Newman NJ. Management of acute retinal ischemia. Follow the guidelines! Ophthalmology 2018; 125: 1597-1607.

[26] Johnston SC, Albers GW, Gorelick PB, et al. National Stroke Association recommendations for systems of care for transient ischemic attack. Ann Neurol. 2011; 69: 872-877.
[27] Easton JD, Saver JL, Albers GW, et al. Definition and evaluation of transient ischemic attack: a scientific statement for healthcare professionals from the American Heart Association/American Stroke Association Stroke Council; Council on Cardiovascular Surgery and Anesthesia; Council on Cardiovascular Radiology and Intervention; Council on Cardiovascular Nursing; and the Interdisciplinary Council on Peripheral Vascular Disease. The American Academy of Neurology affirms the value of this statement as an educational tool for neurologists. Stroke 2009; 40: 2276-2293.

[28] Furie KL, Kasner SE, Adams RJ, et al. Guidelines for the prevention of stroke in patients with stroke or transient ischemic attack. A guideline for healthcare professionals from the American Heart Association/American Stroke Association. Stroke 2011; 42: $227-276$

[29] Olsen TW, Pulido JS, Folk JC, et al. Retinal and Ophthalmic Artery Occlusions Preferred Practice Pattern ${ }^{\circledast}$. Ophthalmology 2017; 124: P120-P143.

(Schneider Miklós dr., Budapest, Mária u. 39., 1085 e-mail: schneider.miklos@med.semmelweis-univ.hu)

\section{"Naturam expellas furca, tamen usque recurret." (Horatius) (Ha vasvillával üzöd is ki a természetet, mégis mindig visszatér.)}

A cikk a Creative Commons Attribution 4.0 International License (https://creativecommons.org/licenses/by/4.0/) feltételei szerint publikált Open Access közlemény, melynek szellemében a cikk bármilyen médiumban szabadon felhasználható, megosztható és újraközölhetö, feltéve, hogy az eredeti szerző és a közlés helye, illetve a CC License linkje és az esetlegesen végrehajtott módositások feltüntetésre kerülnek. (SID_1) 